\title{
DOI 10.26886/2414-634X.7(43)2020.9
}

UDC 791.45.072

YOUNG OLEXANDER KORNIYCHUK: SCREENWRITER AND

FILM DIRECTOR (1929-1934)

\section{Andrii Puchkov, PhD of Art, Professor}

https://orcid.org/0000-0002-0635-6361

e-mail: dr.a.puchkov@ukr.net

National Academy of Educational Art and Architecture, Ukraine, Kyiv

For the first time, the cinematographic heritage of the 1920s by Ukrainian comedian Oleksandr Korniychuk (1905-1972) was comprehensively considered, and an attempt to create a new historical and cultural optics in considering the creative heritage of Soviet playwrights and cinematographers of official ideological orientation was proposed. The degree of importance of studying the author's compositional architecture of the «big mute» at the Odessa and Kyiv film studios in deepening the elucidation of the dramatic principles of Korniychuk's stage work is shown.

Key words: Oleksandr Korniychuk and cinema, Ukrainian cinema of the 1920s, screenwriting.

лауреат Державної премії України в галузі архітектури, заслужений діяч мистецтв України, доктор мистецтвознавства, профресор, А. Пучков, Молодий Олександр Корнійчук: кіносценарист і кіноначальник (1929-1934 роки)/ Національна академія образотворчого мистецтва та архітектури, Україна, Київ

Вперше комплексно розглянуто кінематографрічний спадок 1920-х українського комедіографра Олександра Корнійчука (19051972), пропоновано спробу створення нової історико-культурної оптики у розгляді творчої спадщини радянських драматургів $i$ кінематографрістів офріційного ідеологічного спрямування. Показано 
міру важливості студіювання авторської композиційної архітектоніки «великого німого» на Одеській та Київській кіностудіях у поглибленні з'ясування драматургічних засад сценічної творчості Корнійчука.

Ключові слова: Олександр Корнійчук $і$ кіно, український кінематографр 1920-х років, сценарна майстерність.

Відомо, що Корнійчук писав п'єси, які йшли в усіх театрах СРСР. Відомо, що він за мотивами власних п'єс складав сценарії для кінофрільмів і телеспектаклів. Менш відомо, що працюючи на Одеській та Київській кінофабриках, він - комедіограф - робив сценарії для тодішнього німого кіно, і через це до історії українського німого 1920-х ім'я Корнійчука має бути долучено так само, як воно нині обертається одиноким болідом у космосі історії української радянської драматургії.

На невчасності екранізації п'єси Олександра Євдокимовича Корнійчука (1905-1972) «Фіолетова щука» (1930) під назвою «Приємного апетиту» наголошує академік Вадим Скуратівський, причому перетворює (свідомо?) цю випадковість на політичний прийом і вимагає морального покарання авторів фрільму: мовляв, вийшов на екрани у розпал Голодомору — оповесні 1933-го.

«...Погляньмо на історію національного кіно підрадянської доби. Чи воно якось відрефлексувало ту гіперкатастрофу? ...1933 року вчорашній студент (Київського інституту наросвіти), меткий редактор Київської та Одеської “кінофрабрик” Олександр Корнійчук пише (разом із Хананом Шмаїним) сценарій “Приємного апетиту” - про “окремі недоліки громадського харчування". Тоді ж той сценарій було поставлено. Ось так... Сьогодні, з огляду на безберегий цинізм тієї, сказати б, кіноситуації, годилося б історіографрічно та спеціально фрільмографрічно реконструювати іï - у повному ії гротескно- 
фрактичному складі. Це ж перша - і тоді остання! - “кінорефлексія" на катастрофу...» [2].

Аналогічної позиції дотримується і Сергій Тримбач у передмові до покажчика часопису «Кіно», в якому було надруковано виїмок сценарію:

«Апофреозом стала публікація уривків сценарію Олександра Корнійчука та Ханана Шмаїна “Приємного апетиту”. Фільм з'явився вже голодного 1933-го, і йшлося в ньому про те, як радикально поліпшується харчування трудящих. Справді “актуальні” сюжети, які годі коментувати, - фрільмове мистецтво загалом і журнал “Кіно" зокрема, перетворюються на органи державної пропаганди». [3]

I в обох шановних авторів помилки в написанні імені, що їх я у цитатах виправив (Скуратівський пише: «Хаїм Шмайн», Тримбач «Ханан Шайн»). Та попри це, так фрарби б не згущати, навіть якщо тлом була людська трагедія. До того ж, у п'єсі йдеться не про те, як поліпшується харчування трудящих, а про те, що не слід годувати начальство гнилими щуками: у нього потім діарея і крутить шлунок, а пролетарське населення з цього сміється, і це не дуже для авторитету влади добре. Якщо це «перша і остання кінорефлексія» на трагедію 1932-1933 років, то й направду дуже цинічна — аж до нерозуміння, в чому ж тут, власне, цинізм.

Здається, сучасні дослідники зловтішаються: Корнійчук-сценарист доби Голодомору - так ми на нього всіх дохлих радянських кінособак навішаємо, нехай у труні на Байковому перевертається, гнида більшовицька.

Утім, емоції - осторонь; придивимось до фрактів.

Історія створення фрільму ні в чому не збігається 3 початком Голодомору: повідомлення про перші масові випадки голодування і смертей від голоду після неврожаю 1932 року відносять до початку січня 1933 року (Умань і прилеглі райони), отже коли 14.12.1932 було 
прийнято постанову ЦК ВКП(б) та РНК СРСР «Про хід хлібозаготівлі в Україні, Північному Кавказі та у Західних областях», а 22.01.1933 — директиву ЦК ВКП(б) і РНК СРСР «Про запобігання масового виїзду селян, які голодують» (заборонявся виїзд за межі території України та Кубані), монтаж фрільму «Приємного апетиту» на Одеській кіностудії був майже завершений.

Корнійчук, як і решта радянського людства, знав про драконівський «закон щодо п'яти колосків», ухвалений 7.08.1932, коли п'єса вже два роки як існувала й перетворена Євдокимовичем на кіносценарій ще десь наприкінці червня 1932-го. Чому саме тоді?

По-перше, теоретично: тому, що сам Корнійчук у січні 1930-го емоційно висловився з хронології підготовки фрільмів:

«Наше мистецтво взагалі не встигає за тим шаленим темпом, якого набуло життя. В кінематографії ж специфічні умови виробничого процесу ще більш утруднюють можливість іти в ногу з життям. Сировина (брак якої тепер дуже заважає нормальній роботі) сценарій - виготовляється протягом 5-6 місяців, фрільмують приблизно стільки ж, таким чином, на виготовлення фрільму треба біля року, а за цей час наше життя встигає піти далеко наперед». [4]

Отже початок роботи над фільмом можна вірогідно датувати січнем-лютим 1932-го, коли про неврожай осені 1932 року, звісно, ще й гадки не було.

По-друге, практично: в серпневому числі часопису «Кіно» за 1932 рік ішлося про незадовільну роботу Одеської кіностудії в першому кварталі (січень-березень) та «позитивний перелом» у другому кварталі (квітень-червень), про нові кінофрільми «Качиний ніс», «Нові дерев'яні конструкції», «Кахівський плацдарм», а також про фрільм «Гайдамаччина» (режисер І. Кавалерідзе, оператор М. Топчій) і «майбутню кінокомедію» «Приємного апетиту» (сценарій О. 
Корнійчука та Х. Шмаїна, оператор М. Бєльський). [5] Тобто вже в червні йшлося про готовий сценарій Корнійчука і Шмаїна, виїмки якого були надруковані в тому ж числі з коментарем автора, що сховався під псевдонімом «Іверс». [6] Матеріал мав потрапити до редакції часопису не менш, як за місяць-півтора до публікації, — приблизно в червні 1932 року. Та вже 30.10.1932 московська «КиноГазета» писала про фрільм «Приємного апетиту» як про такий, що ось-ось має вийти на екрани. Майже через рік, 10.09.1933 та сама «КиноГазета» та 1.10.1933 «Вечерняя Москва» писали про фрільм достатньо прихильно, і, можливо, ці публікації, що вийшли вже після вщухання Голодомору, лише і можна зарахувати як відголос трагедії: влада знала, що робить. Але ж те, що кіно вийшло в самий розпал Голодомору - взимку 1933го - вини ані Корнійчука, ані Шмаїна, ані Одеської кіностудії немає: партія і уряд не ставили творчих людей до відома про свої нелюдські плани. Чи варто тепер поєднувати начебто одіозне ім'я Корнійчука 3 його вигаданим цинізмом щодо ілюстрування трагедії, та ще й у такий безбожний спосіб?

Це майже те саме, як звинувачувати у потуранні злочинній політиці партії Іллю Ільфа і Євгенія Петрова, які в «Золотому теляті» (1931) зобразили старого кухаря Івана Осиповича у нафталіновому фрраку. Він колись годував принца Вюртемберзького, а тепер вимушений годувати будівельників залізниці в степах Казахстану.

«Покуда шёл митинг, он нервничал, поглядывал на солнце и покрикивал на кочевников, которые просто из любопытства пытались въехать в столовую верхом. Старик замахивался на них салфеткой и дребезжал:

- Отойди, Мамай, не видишь, что делается! Ах, господи! Соус пикан перестоится. И консоме с пашотом не готово!». [7] 
Вони просто написали смішну річ, де здоровий глузд старого часу накладено на здоровий глузд новизни. Фільм за сценарієм Корнійчука та Шмаїна, присвячений маже тому самому - як нове бореться зі старим, і в якому знялися, зокрема, Мар'ян Крушельницькій (Жеребков = Звєздоплюєв) та Амвросій Бучма (кухар Карпо Бобов), швидко поклали на полицю. Добродій «Іверс» назвав комедію однією з кращих на тодішньому екрані. [8] Отож, Кобилецький помиляється, коли пише, що кінофрільмам за сценаріями Корнійчука початку 1930-х преса не приділяла уваги, «майже обходила» їх. [9]

1930-го Корнійчук спільно с Павлом Долиною (1888-1955) написав сценарій фрільму «Чорні дні» за документальним твором Володимира Короленка «Сорочинська трагедія» (1907) - про селянське повстання в січні 1906-го у селі Сорочинці під час так званої «російської революції 1905-1907 років». Жандарми арештували активного місцевого мешканця, селяни повстали і захопили село. Донські казаки і кавказькі черкеси за урядовим наказом придушили повстанців, які, розгубившись, не знали, що зі своїм захопленим селом робити. Про цей фрільм часопис «Кіно» згадував принаймні вісім разів у статтях, присвячених фрільмам про 1905 рік, друкував кінокадри.

Того ж року вийшов на екрани фрільм режисера Лазаря Френкеля (1904-1978) «Деа промфінплани» (інші назви: «Будівники», «Свій хлопець»), знятий німецьким оператором Йозефом Роною (1878-?) на Київській кінофабриці за сценарієм Корнійчука.

«Режисер Л. Френкель починає режисерську розробку сценарію Корнійчука до фрільму “Два промфінплани”, що покаже в комедійних тонах прорив промфінпланів на кінофабриці та на великому

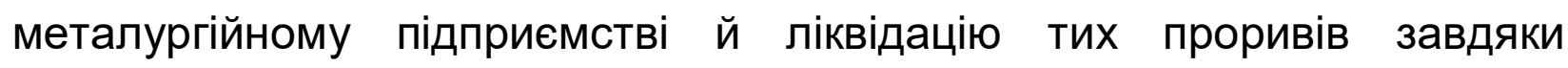
змаганню комсомольських ударних бригад обох підприємств. Фільмуватиме оператор Й. Рона». [10] 
Олексій Каплер згадував, що Рона був одним із трьох німцівоператорів, які працювали в Одесі, причому Рон був типовим німецьким селюком - неповороткий, захланний, він повільно розумів і знущався над прикріпленим до нього випускником Одеського кінотехнікуму, узагалі - «німчура, яка надуває щоки». Павло Нечес взявся його перевиховати.

«Никто никогда не узнал, о чём говорил Павло господину Рону, ибо сидевший в соседней комнате секретарь дирекции Юрий Михайлович, тихий, застенчивый человек, заслышав из кабинета первые же слова Нечеса, выскочил в сад и не возвращался до конца рабочего дня <...> Ребята из лаборатории № 2 видели, как Рона на согнутых ногах выходил из здания конторы и божились, что волосы у него стояли дыбом». [11]

Тепер із вихованим у лобовий спосіб німецьким колегою можна було спокійно працювати. Серед хлопців 3 лабораторії № 2 («комсомольського відділу» кіностудії) був і ії завідувач спостережливий Корнійчук.

Сюжет фрільму: на кабельний завод приходить студент-практикант Лопухов, який швидко стає «своїм хлопцем». Невдовзі його призначають на посаду інженера замість звинуваченого у шахрайстві крадійкуватого Штокмана. Водночас Лопухов товаришує з колишнім однокурсником, сином Штокмана, і вирішує будь-що досягти «красивого життя» - не гірше, ніж у Штокмана. Звістка про вагітність дружини ламає його плани, і він наказує їй зробити аборт, однак замість аборту Ніна подає на розлучення. Лопухов під впливом Штокмана йде на посадовий злочин (продає йому заводську арматуру); його викривають і заарештовують. Колишня дружина після закінчення інституту повертається на завод. [12] 
1931-го (або 1932-го) Корнійчук переїхав до Одеси і за путівкою ЦК ВЛКСМ став працювати на тамтешній кінофабриці завідувачем відділу. [13]

Важко позбутися епізоду із «Золотого теляти», що міцно засів у пам'яті: Остап Бендер намагається продати на Першій Чорноморській (тобто, Одеській) кінофабриці сценарій багатометражного фрільму «Шия» і отримати за нього 900 карбованців. Бендер потрапляє на територію фабрики, де всі метушаться і пересуваються підтюпцем, крім головного бухгалтера («товариш Супругов»), який, не надто вникаючи, замість дев'ятисот практично мовчки видає невідомому автору невідомо за що триста карбованців. У 1930-му, коли писався роман, німе кіно вже не працювало через настання ери звукового кіно, а звукове кіно ще не працювало через організаційні неполадки, пов'язані з ліквідацією ери німого кіно. [14] Коли Корнійчук скаржитиметься, що в такому-то кварталі такого-то року фрільми не знімаються, можливо, він пам'ятав цей виїмок із «Золотого теляти» і тихенько, по-єзуїтському посміхався.

В Одесі замість його улюбленого гарбузового насіння їжею була тюлька.

«Деякий час ми жили з Миколою Бажаном. Скрутно жили. Найкращим харчем була тоді у нас тюлька. Бувало, майнеш на Привоз, купиш кілограм тюльки і розкошуєш. Вода тільки п'ється». [15]

Тут за його спільним з Хананом Шмаїним сценарієм з'явився сатиричний фрільм «Станція “Пупки” (або «Свині завжди свині»; реж. Ханан Шмаїн, оператори Павло Радзіховський, Володимир Горіцин, худ. Сергій Худяков). Авторство Корнійчука у цій стрічці засвідчено: кінорежисер Тимофій Левчук, слухач Корнійчука на сценарних курсах, пише, що в сонячній Одесі, під час роботи з Іваном Кавалерідзе над фрільмом «Коліївщина», він часто перетинався з Корнійчуком, бо там 
же, в павільйонах Одеської студії, режисер Шмаїн за сценарієм Корнійчука знімав веселу комедію “Станція “Пупки”». [16] 2015 року примірник фрільму російський кінознавець Петро Багров знайшов у берлінському Бундесархіві; зусиллями Посольства України влітку 2016го його передано до Національного центру Олександра Довженка, в листопаді І. Козленко, директор Довженко-Центру, запостив повідомлення:

«"Свині..." - неймовірно дотепна, динамічна комедія, в якій водночас висміюються радянський бюрократизм, доведений до абсурду цілковитим безладом та саботажем фрормалізм, міщанство та провінціалізм, далекі від історичних викликів доби <..> "Свині завжди свині" - повнометражний режисерський дебют Шмаїна <...> В будь-якому разі, комедії <...> найдошкульніше оголюючи всі вади радянської тоталітарної системи <...> першими підпадали під заборону й нерідко навіть не виходили на екрани. На сьогодні відомо заледве 5 збережених українських німих кінокомедій. "Свині..." - поза всяким сумнівом одна з найкращих». [17]

Чи додасть «Свиням...» авторство Корнійчука якоїсь моральної якості, чи трохи «виправдає» його серед нас, нащадків?

Останнім фрільмом 1930-х, поставленим начебто за сценарієм Корнійчука, був звуковий «Останній порт» («Незабутні сигнали», 1934, прем'єра 1935, один $з$ перших звукових фрільмів). Його зробив Арнольд Володимирович Кордю́м (1890-1969) начебто за майбутньою п'єсою Корнійчука «Загибель ескадри». Всупереч Кобилецькому, який уважав, що «Останньому порту» не пощастило у друкованому висвітленні, слід розповісти майже детективну історію.

Кінокритик Л.Гень, заступник редактора часопису «Кіно» й виконуючий обов'язки відповідального редактора, в статті «Екран на службу оборони» (Кіно. 1932. № 19/20 [127/128]. С. 15-16) згадує, що 
1932 року Одеська кіностудія працювала над чотирма фрільмами: «Кахівський плацдарм», «Рейд», «Океан» та «Загибель ескадри» (реж. А. Кордюм). Утім, відомо, що п'єсу з аналогічною назвою написано Корнійчуком лише 1933 року, сценарій однойменного фрільму - 1934 року, а на екрани він вийшов 1935-го.

Це хронологічне непорозуміння стало причиною декількох публікацій, в яких Корнійчука злорадно звинувачено у плагіаті.

Що таке плагіат? Прометей до певної міри теж був злодієм.

Можна слідом за Тимофрієм Пніном пожартувати?

«Культура вообще живёт воровством. В творчестве таится вор, в хищении зреет восхищение, искусство начинается с искуса, а красота, похоже, постоянная спутница глагола “красть". В конце концов, в основе греческого слова auctor - глагол augeo, означающий “присоединение" и “приумножение”. Увидев роскоши Версаля, Маяковский отчеканил фрормулу природы прекрасного в его национальном понимании: “Таких и вторых построить нельзя, / Хоть целую жизнь воровать". Но как рождается шедевр? Талант - находит, гений - крадёт <..> Особой изощрённостью отличаются похитители сюжетов. Они маскируются так тщательно, что и не поймёшь: то ли со шпаргалки списывал, то ли в зеркало подглядывал. Цепляясь за Стендаля, Лермонтов пишет “Героя нашего времени” (Печорин начинает сюжет там, где Сорель его завершил). Заглядывая в “Идиота", сочиняет “Фиесту" Хэм (совпадает не только расклад ситуаций, но и финальная фраза, хотя образ главного героя вывернут наизнанку). Переиначивает гоголевскую “Шинель" Акутагава: в “Бататовой каше" герой получает желаемое в огромных размерах...

Похищение же идеи можно сравнить с киднеппингом. Гончаров до самой смерти был уверен, что Тургенев уволок замысел “Обрыва”, да и написал “Дворянское гнездо”. 
Бродячие сюжеты, любимые темы, вечные вопросы. Где же кончается заимствование и начинается плагиат?». [18]

Нi, читачу, я не збираюся цією дотепною лірикою виправдовувати нечесність сучасних дисертантів, які методом «Ctrl-C + Ctrl-V» шиють «наукові тексти» зі шматків поганих мережних рефератів і недолугих вишівських посібників. Не збираюся і сперечатися з тими дослідниками, які, посилаючись на авторитети, показують, що сюжет п'єси «Загибель ескадри» Корнійчук украв у режисера Кордюма і прозаїка Охременка.

А ще натякають, що це Олексій Миколайович Толстой допомагав доводити текст «Загибелі...» до пуття. Втім, що поганого в тому, що досвідчений російський граф «творчо допоміг» молоденькому початківцю - «комсомольському графу» - в його літературних справах, що від того стали лише кращими? Люди одного суспільного страту мусять допомагати один одному.

Серед аргументів є смішні (приміром: як міг початківець у 28 років написати епічну драму про моряків, виявити неабияку обізнаність із флотськими звичаями, побутом, мовою? Не забуваймо, що перша п’єса Ґенріка Ібсена «Богатирський курган» ішла на норвезькій сцені, коли автору ледь виповнився 22 роки), $є$ начебто документально переконливі [19]: з посиланнями на спогади Гуменної (ї̈ упереджене ставлення до Корнійчука є наочним), на свідчення Юрія Тамарського і спогади Арнольда Кордюма «Прошлое, которое остаётся с нами» (1965). Розповідь Кордюма «доби хрущовської відлиги» зведено до того, що сюжет майбутньої стрічки під назвою «Загибель ескадри» Кордюм склав із київським прозаїком Вадимом Охременком. [20] Але той через постійні відрядження (кореспондент «Правды» в УРСР) був змушений відійти від роботи над фільмом. Режисер звернувся по допомогу в сценарний відділ, познайомився там із Корнійчуком і показав йому незавершений сценарій. Сюжет драматургові 
сподобався, і він згодився допомогти довести його до пуття. На титульному аркуші сценарію з'явилися прізвища його авторів Кордюма і Корнійчука. Потім Юрій Тамарський, оператор «Останнього порту» сказав, що «на початку своєї драматургічної кар'єри Олександр Корнійчук уславився тим, що вкрав сюжет "Загибелі ескадри” та подав його на конкурс нових театральних п'єс як свій».

Не стану далі переказувати дослідницьку аргументацію. Ліпше перекажу свідчення Івана Ле (1895-1978) про історію створення п'єситрагедії і сценарію фрільму, оскільки на них із сучасних обвинувачів ніхто увагу не звернув.

Корнійчук, мешкаючи в харківському готелі, раптом рішучо відмовляється їхати 3 Іваном Леонтійовичем до Москви на якийсь пленум, мотивуючи тим, що працює над новою п'єсою. Шкода, що немає хоч приблизної дати цієї події. Навіть тему і назву Корнійчук не назвав, хоча Ле кортіло знати.

В інтерв'ю часопису «Червоний шлях» (1933. № 10) Корнійчук зізнавався, що

«разом із режисером Шмаїним написав комедійний сценарій “Приємного апетиту” (фрільм уже вийшов) та з режисером Кордюмом тоновий сценарій “Незабутні сигнали”, що зараз фільмується. Тепер я працюю й закінчую п'єсу трагедію “Загибель ескадри”. Матеріал п'єси - історичний факт виключного значення - загибель Чорноморської ескадри 1918 року» (5 : 121).

Про «Незабутні сигнали» жодних інших свідчень я не знайшов, але вказівку на роботу над «Загибеллю ескадри» вважаю точною: нема кому і для чого було фальсифікувати це повідомлення. Якщо число «Червоного шляху» було подано до складання за пару місяців до жовтня (коли журнал з інтерв'ю вийшов), це свідчення слід віднести до кінця літа 1933 року. 
Корнійчук розповів Іванові Дузю деталі:

«Основним збудником для творення п'єси була книга старшого лейтенанта В. Кукеля “Правда про загибель Чорноморського фрлоту 1918 року" [21], фрактичного командира есмінця "Керчь”, що потопив ту частину ескадри, яка відмовлялася повернутися 3 Новоросійська в Севастополь. Це об’єктивна, підкріплена документами розповідь активного учасника тих героїчних і трагічних днів. Але тільки об'єктивна розповідь» .

Далі - звичайна міфологія, рятівне камлання:

«Цього для мене було мало, і я звернувся до праць Володимира Ілліча Леніна». [22]

У виступі на нараді працівників театрального мистецтва в Харкові у листопаді 1933 року Корнійчук знову каже про нову п'єсу:

«Понад два роки тому я почав працювати над п'єсою (тобто приблизно 1931 року. - А. П.). Спершу здавалось: "Загибель ескадри... 18-й рік...” Треба, значить, показати тих самих “братішків”, яких я до того бачив в інших п'єсах. Почав працювати. Написав я, здається, три картини, прочитав їх товаришам письменникам, критикам. "Нічого, - говорять, - публіка на "ура" сприйме..."

Поїхав потім у Севастополь, де, як мені казали, зараз працюють учасники подій 18-го року» (5 : 136).

Що було потім, дізна́ємося іншим разом, тут важливо вказати на дату початку роботи над п'єсою: приблизно 1931 рік.

А тепер Іван Ле:

«Саме в ці роки винесла мене доля на посаду завідувача художнім відділом у новій, ще й не добудованій [за проєктом архітектора Валеріана Рикова] Київській кінофрабриці. То була марудна праця організатора, починаючи від сценарію і аж до готового фрільму. Художній відділ прийняв на себе величезний потік, просто зливу 
сценаріїв, а це ще й режисери, численні їхні штати на виробництві картини, це й актори. В тих кадрах на той час опинився й Арнольд Кордюм зі своєю згодом голосовою “Джальмою” і... зі сценарієм на тему загибелі ескадри! Для мене сама тема не була новою, бо ж я знав, що над нею працює Корнійчук.

Одного дня до мене зайшов Арнольд побалакати про свою творчу “невдачу”. Невдача полягала в тому, що Корнійчук майже два роки вже працював над п'єсою “Загибель ескадри”, закінчує їі. А він, не знаючи про це, працював над сценарієм. Радимось, зіставляємо терміни початку праці обох і доходимо висновку, що найправильніше буде поговорити Кордюму про це з самим Корнійчуком. Кордюм, звісно, не впав у розпач, дізнавшись про такий збіг. Безперечно, для нього, як i для кінофабрики, тема загибелі ескадри багато важила. Але ж і Корнійчук як автор кіносценарію цілком задовольнив би нас.

Корнійчук навдивовижу спокійно, навіть з ентузіазмом сприйняв повідомлення Кордюма. Другого ж дня вони обидва приїхали в Київ. Звісно, я був радий зустрічі.

- Іване, голубчику, що за тривога тут у вас? Та це ж прекрасно! Теми загибелі ескадри вистачить на десятки творів у всіх існуючих жанрах. Я написав п'єсу, поки що - варіант. Та п'єса - це мій творчий жанр драматурга. Кордюм - кінорежисер і сценарист по цій же темі. Я охоче допоможу вам створити кіносценарій... Тим паче, що і Кордюмом зроблено багато. Добре було б загітувати когось із прозаїків на цю тему. От і романюга вийшов би!». [23]

Певно, не варто підозрювати Іван Ле в бажанні якось вигородити «плагіатора» Корнійчука, який «украв» у Кордюма сюжет. Звідси зрозуміло, що на п'єсі стоїть одне авторське ім'я, а на сценарії - два: Кордюм і Корнійчук. Тому на здивування сучасних дослідників тим, що в Корнійчука підступно «піднялася рука» подати п'єсу на всесоюзний 
конкурс лише за власним іменем, слід здивуватися своєю чергою: він же не обопільний сценарій подавав, а власну п'єсу.

Думку:

«17 лютого 1933 року, коли стрічку саме фільмували, Раднарком СРСР оголосив Всесоюзний конкурс на найкращу радянську п'єсу. Корнійчук зрозумів: це шанс пробитися. Але оскільки з його власним доробком у Москву не поткнешся, він і скористався майже готовим сюжетом про останні дні чорноморської ескадри» [24] - слід вважати як не намаганням принизити автора п'єси «Загибель ескадри», то дослідницьким непорозумінням.

Постанова РНК СРСР про оголошення конкурсу була прийнята 17.02.1932, тобто роком раніше; стрічку почали фільмувати 1934-го, вийшла вона на екрани 1935-го, і домовленості співавторів сценарію були дотримані. Вакуленко вважає, що неувага до фільму пояснювалася появою п'єси, яка і привернула увагу критики. Втім, сучасні дослідники «нагнітають обстановку»: мовляв, подальші долі учасників цього фрільму склалися трагічно через примару всевластя ОДПУ, з яким співробітничав Корнійчук - ну, не міг не співробітничати такий успішний молодик. Так, Кордюм був «змушений залишити ігрове кіно, виїхати з Києва й фільмувати в Узбекистані» (у 1935-1940 роках працював на Ташкентській кіностудії, де 1939 року зняв ігрове кіно «Азамат»); Тамарський пішов у документальне кіно, «а згодом узагалі опинився в Бразилії» - направду просто втік разом із німцями й іншими українськими діячами 1943 року від «визволеного» Радянською армією більшовицького раю. 3 акторів: Петро Масоха 17 років не знімався (неправда: знімався у фільмах «Інтриган» (1935), грав Івана Половця у «Вершниках» за Яновським і червоноармійця у «Щорсі» 1939 року), Луку Ляшенка двічі заарештовували, Степана Шагайду розстріляли (найпевніше за компанію з Лесем Курбасом, ніж за зйомки 
в одному із 26 фрільмів). «Випадковий збіг чи прибирання небажаних свідків?» Свідків чого? Навряд чи є здоровий глузд у звинуваченні власно створеної міфології в розпливчастості й невідповідностях.

Ще доводиться читати про Корнійчука таке, найновітнє:

«Не без впливу цього “комсомольського графра" на 10 років засудили критика Петра Колесника, заборонили фрільм Івана Кавалерідзе “Прометей”, режисера Григорія Чухрая звільнили 3 кіностудії ім. Довженка, Гната Юру позбавили керівних повноважень у театрі ім. Франка, а Максима Рильського включили до "чорного списку" Кагановича». [25]

Звідки авторка черпає відомості? Напевно, з тієї самої міфології. Якщо вірити іншим міфрам, фрільм «Прометей» (за мотивами творчості та біографрії Шевченка) заборонили 1936-го на вимогу Сталіна: вождю начебто не сподобалося, що на екрані росіяни програють війну на Кавказі. Петро Колесник 1934 року активно цькував Миколу Зерова, виступив із наклепницькою статтею «Плач Ярославни, або Агонія буржуазно-націоналістичної камени» («За марксо-ленінську критику». 1934, № 4) і був засуджений за доносом - чому саме Корнійчука? Григорій Чухрай працював на Київській кіностудії (тоді ще не «імені Довженка» - той був живий) у 1953-1955 роках, звідки спокійно і радісно перейшов на «Мосфільм». 3 нащадком наполеонівського солдата і засновником Театру імені Франка, який ставив всі п'єси Корнійчука з «Макаром Дібровою» включно, Гнатом Юрою трапилося таке: 1954-го з Москви прийшов наказ зняти його з посади головного режисера («за власним бажанням»), призначити на посаду харків'янина і курбасівця Мар'яна Крушельницького: Юра став рядовим артистом і режисером. За рік схаменулися і зробили його художнім керівником, Крушельницького - головним режисером. Пояснили в ЦК: «Тепер керуватимете вдвох, як ото у MXАТі Станіславський i 
Немирович!» - «А хто з нас буде Станіславським?» - незворушно спитав Юра.

«Дружбу Корнійчук і Юра пронесли через усе своє життя, незважаючи і на деякі розходження та незгоди, що, природно, іноді виникали. Та я добре знаю, бо не один раз чула від Олександра Євдокимовича і від Гната Петровича, що взаємна пошана і любов між ними залишилися незмінними». [26]

До сімдесятиліття Гната Юри (січень '1958) Корнійчук оприлюднив у «Вечірньому Києві» (31.01.1958) привітання, де є таке славослів'я:

«Не тільки вистави за моїми п'єсами, а й усі інші спектаклі класичної спадщини і радянської драматургії, які ти поставив як великий режисер, всі образи, які ти створив, самобутній колоритний актор, виразно позначені ідейною партійною спрямованістю, глибокою народністю й правдивістю, яскравою театральністю <..> Творчі зустрічі з тобою, творча радість у нашій спільній багаторічній праці у Театрі імені І. Франка назавжди лишаться в моєму серці» (5 : 343).

Однією рукою писати здравиці, а іншою кляузи - не було в характері Корнійчука: попри всі особливості його характеру, двоїстість його душі, зумовленої часом, обставинами і «місцем дії», він все ж таки був чемною людиною, і опускатися до наклепів собі не дозволяв. (На відміну від щиросердної Наталі Михайлівни Ужвій. «Вона розрядилась на адресу Леся Курбаса обвинуваченнями, яких не чути було навіть із уст "вусппівських" погромників. Та сама Наталія Ужвій, яка кілька днів тому з ревними сльозами на очах клялась своєму вчителеві Лесеві Курбасові в невідступності й вірності його мистецьким постулатам і його твориву театрові “Березіль”, - тут, теж із сльозами на очах... жалілась партійному чиновникові на “диктатора" режисера, який паралізував іiї творчу індивідуальність, відривав співробітників театру від радянської дійсності» [27]). 
Про «чорний список» Кагановича 3 Максимом Рильським промовчу: треба звернутися до спогадів Хрущова - там ціла історія, як Сталін наказав: «Передай этому дураку Успенскому - пусть не трогает Рыльского» (йдеться про список наркома внутрішніх справ УРСР Успенського, який подав його Хрущову на затвердження).

Усе, крапка. Більше не звертатиму увагу на такого роду «розвінчання ганебної, антилюдяної діяльності» Корнійчука, назавжди зупинюсь у деміфологізації його постаті. Втім, приємно, що постать ця все ж таки перебуває посеред сучасної наче наукової уваги в такий чудернацький, укотре перекручений спосіб.

Але заради правдивості згадаю один призабутий займавий документ, який ані Корнійчук за життя, ані упорядники його посмертного п'ятитомника 1986-1988 років не включили до зібрань текстів.

Мовлю про його доповідь на Першій кінонараді при ЦК ЛКСМУ «Творча метода української радянської кінематографії» влітку 1931 року в Харкові.

26-річний начальник юнацького сектору Київської кіностудії, автор вже двох п'єс і двох кіносценаріїв, який невтомно працює над «Штурмом», «Станцією “Пупки”», «Фіолетовою щукою» та її кіноваріантом «Приємного апетиту», викроює час для укладання розміром у більш ніж друкований аркуш власного бачення фрорм становлення українського кінематографу після прийняття 1929 року першого тематичного плану фрільмування на Київській та Одеській кіностудіях. Намагається не так для аудиторії, як для себе розібратися, яким шляхом слід рухатися, аби тебе нормально сприймали в творчому кінотоваристві.

Коли Кузякіна 1958 року казала, що гострота інтуїції Корнійчукадраматурга виявилася в тому, що він зумів відчути нові потреби, які 
висувало життя, що ось-ось мусили стати «на порядку денному», і на повний голос заговорив про них [28], - вона, найімовірніше, сама не до кінця розуміла, наскільки влучним було таке спостереження. Зовсім молодою людиною Корнійчук зрозумів принцип «тримати носа за вітром», якщо хочеш бути пластичним і витривалим, щоб тебе не можна було застати зненацька, в стані творчого розпачу.

У доповіді Корнійчук розглядає декілька фільмів останніх двох років (1929-1930) щодо їхньої відповідності запитам пролетарської культури. Ми вже відвикли від такого роду текстів, розшукати їх важко, тому прошу трошки згадати, в якому словесному лайні вимушено перебувала радянська людина.

«Особливості реконструктивного періоду, періоду успішної побудови фрундаменту соціалізму в країні Рад, успішна боротьба 3 рештками капіталізму в нашій країні, ліквідація куркульні як класу, боротьба на два фронти з правою небезпекою, як головною, та лівими закрутами, боротьба з великодержавним та місцевим шовінізмом, колосальні зрушення в нашій економіці внаслідок успішного виконання п'ятирічного плану, - все це не тільки висуває низку нових проблем перед мистецтвом як надбудовою, але и примушує його перебудуватись, щоб стати справжньою зброєю в руках пролетаріату, в боротьбі за соціалізм» [29]

Після таких застережень чекати на щось приємне не слід.

Корнійчук послідовно дає по шапці Дзизі Вертову:

«Фільми Дзиґи Вертова “Одинадцятий”, “Людина з кіноапаратом”, “Ентузіазм” - ми бачимо, як режисер неспроможний відбити процеси індустріалізації нашої країни, процеси соціалістичного будівництва, ентузіазму робітничих мас, а замість цього є окремі шматки машин, заводи, димарі, за якими не видно людей. Цілеспрямованість фрільму режисер рятує написом, але це не допомагає. Складні соціальні 
проблеми підмінюються рухом машин, рухом продукції заводів трактори, комбайн тощо».

Потім - його брату Михайлу Кауфрману:

«Коли згадати “Весну” (правильно: “Оповесні”. - А. П.) Кауфмана, де естетський підхід до матеріалу яскраво позначився, особливо в тих місцях, де Кауфман вдається до біологізму (весна в природі) і ці біологічні категорії ставить поруч з категоріями соціального порядку, зводить соціальні процеси до біологічних, все це примушує нас шукати коріння цієї “творчої” методи. Ці коріння треба шукати в світогляді представників цієї школи представників дрібнобуржуазної інтелігенції, попутників в кіномистецтві». [30]

Дісталося й Довженкові, але більш тонко, вітіювато, з надміром туманної марксистської риторики:

«“Земля” Довженка революційний фрільм високої художньої майстерності, але в основі своїй механістичний. Механістичність фрільму - зведення складних соціальних процесів класової боротьби на селі до процесів біологічних. В цілому фільм в час його виходу на екран вже був відсталий від життя - від тих процесів, що точились на селі. Сам Довженко з'ясував це тим, що фрільм робиться 8 місяців, і тому не можна догнати життя. Така діалектика була цілком вірно схарактеризована тов. Воробйовим у журналі “Критика" як арифметика, а не діалектика. I справді, справа не в часі, а справа в світогляді, творчому методі режисера. Творчий метод режисера Довженка на той час базувався не на методі матеріалістичної діалектики, а стояв між ідеалізмом та матеріалізмом». [31]

Про що саме йдеться, слід перепитати у марксистів, та звідки зараз їх узяти? 
Але не варто вважати Корнійчука простим погромником. Він погромник вдумливий - точно вказує і на позитив. Приміром, щодо Вертова і Кауфмана з «Кіноока»:

«Що позитивного було в цій школі? Це те, що на першому етапі розвитку нашої радянської кінематографії, коли на наших екранах квітнув псевдореволюційний фрільм, коли не було ще нових кадрів і режисери 3 дореволюційною буржуазною кінематографрічною практикою створили радянську революційну “клюкву”, школа кінооківців вперше подала нам фракти соціалістичного будівництва, нехай поверхово, механістично, але на той час, серед зливи псевдореволюційних фрільмів, це був певний революційний крок, вони перші підійшли до робітничої тематики, хоч і не могли заглибитись, не могли охопити явища в їх діалектичному розвиткові, діалектичній єдності протилежностей, не піднялися до синтези певних соціальних процесів». [32]

А ось щодо Довженка, курсивом:

«На цій нараді ми не можемо не відзначити, що тов. Довженко перший режисер, який з дня організації юнацького сектору на київській кіноффабриці надзвичайно чуйно поставився до його роботи $i$ ввесь час допомагав $і$ допомагає в роботі молодих режисерівкомсомольців, цим допомагає нам в створенні нових пролетарських кадрів». [33]

Уміє молодий кіноначальник знайти позитивне навіть у таких запеклих формалістів і механіцистів, антидіалектиків, техніцистів, махістів, буржуазних запроданців і взагалі людей хибного світогляду, як Вертов, Кауфман і Довженко, Кордюм і кінокритик тов. Савченко; натомість у «кінокритика тов. Єрофрієва» він нічого позитивного знайти не зміг - так і лишився тов. Єрофеєв з його негативностями. 
Дісталося фрільмові Арнольда Кордюма «Вітер з порогів» (або «Останній лоцман», 1929): будинок старого лоцмана, який все життя водив судна через Дніпрові пороги, призначений на злам через будівництво Дніпрогесу. Найбільше журиться батько: гине звичний уклад великої родини. Але діти, що стали першими будівельниками Дніпрогесу, не поділяють переживань старого.

Чи не вбачаємо тут тематичну перекличку з «Кам'яним островом»? Може, теж запідозрити Корнійчука у викраданні сюжету?

Утім, прискіпливий Корнійчук карбує вбивчі вади фрільму:

«Режисер Курдюм (він тоді ще не був Кордю́мом. - А. П.) боровся зі сценарієм, переробляв кілька разів, але перемогти остаточно не зміг, і на екран вийшов, що особливо болюче, з-під рук комуніста, фрільм, в якому змазана класова боротьба <..> В фрільмі залишилось соціалістичне будівництво Дніпрельстану мертвим, статичним, не кінематографрічним, а фоотографрічним масивним тлом. Замість величі соціалістичного будівництва у фрільмі шароваристе “українське” село, натуралізм найпоганішого ґатунку так званих малоросійських театрів. (Весілля, безконечне пияцтво, лоцмани по-християнському, біля Миколи святого моляться перед від"їздом, парубки у вишиваних сорочках тощо.) Жодної класової диференціації, все підмінене боротьбою традицій. Отже, самий матеріал сценарію, його ідейне спрямування притягло режисера до театральщини солоденьких естетських пейзажів, до ультранатуралістичного смакування деталей (скубуть курей, киплять казани, готуються до весілля заквітчані парубки і мчить на возах п'яна ватага). Отже, цей провал режисера Курдюма для нас цікавий не взагалі, а він мусить поставити руба питання про кадри сценаристів, про кадри людей, що дають ідейну основу майбутнього фрільму». [34] 
Неважливо, що потім, за два роки, з Арнольдом Володимировичем й згаданим оператором Йозефом Роною, який фрільмував «Вітер 3 порогів», Корнійчук робитиме фрільм «Загибель ескадри». Важлива важкість розуміння: що хотів сказати доповідач, яку саме думку донести? Про відсутність у фрільмі «класової диференціації»? Кого 3 ким диференціювати - батька з дітьми? Лоцмана з будівельниками? Чим він бажав би замінити український колорит фрільму? Яким інтернаціоналізмом? I це - на Дніпрових порогах?

На такій облудній риториці побудовано всю доповідь.

Утім, висновки за нею достатньо конкретні: 1) засміченість кадрів української кінематографії дрібнобуржуазними митцями, які заважають лівим попутникам боржій наблизитись до пролетарських митців і мають на них великий вплив; 2) певне опортуністичне ставлення незначного партійного ядра, що працює в українській кінематографрії, до процесів диференціації (чого? кого з ким?), до процесу створення міцного пролетарського ядра; 3) ізольованість від пролетарської літератури, від іï основних організацій ВУСПП, «Молодняк»; 4) відсутність планової підготовки пролетарських кадрів; 5) відсутність консолідації комуністичних пролетарських сил на кінофронті; 6) низький теоретичний рівень і кустарництво в методах роботи, квола боротьба за опанування фрілософії пролетаріату - марксистсько-ленінської діалектики. [35]

3 одного боку, вся ця нудота - «побудова соціалізму екранними засобами» (Є. Марголіт) - не в'яжеться з репліками персонажів його «молодих» п'єс, з іншого, - яким щитом, якою бронею гучних і фальшивих (себто «правильних») слів Корнійчук прикривав справжню творчість, причому, здається, робив він це 3 такою самою невимушеністю, як і писав п'єси. Йому навіть це подобалося, свідчило про неабияку майстерність нанизування «правильних» слів одне на 
одне, і неважливо, що там іноді мало смислу - важливо, що є запал, що він може бути і трибуном, може «глаголом жечь» серця полохливих слухачів, які мусили всю цю «галіматню» (М. М. Дьомін) вислуховувати.

Але Корнійчук був настільки витончений у підтекстах, що лише компаративні вправи дають можливість переконатися у цьому.

Приміром, у «Фіолетовій щуці»:

«Оксана. <..>> Проблеми складні. Ми на засіданнях семінару розбираємо деборінщину.

Марія. Що таке?

Оксана. Ухили філософа Деборіна. Хлопцям важко. Bсе це складна матерія, тонка. I хоч не все зрозуміло, але захоплення велике» (1:162).

А ось у доповіді:

«Боротьба за правильну ленінську лінію широко розгортається на ідеологічному фронті, зокрема в фрілософрії (боротьба проти деборінщини, меншовикуючого ідеалізму та механіцизму), в літературі (боротьба з переверзіанством, нацдемівщиною, воронщиною) тощо». [36]

Приміром, про академіка Деборіна пам'ятають лише записні історики радянської філософії: партійною постановою «Про журнал “Под знаменем марксизма”» (25.01.1931), яким керував Деборін, визначено, що, «відриваючи фрілософрію від політики, не проводячи в усій своїй роботі партійність фрілософії і природознавства, [група,] яка очолювала журнал “Под знаменем марксизма” [Деборін, Карєв, Стен та iн.] воскрешала одну із шкідливих традицій і догм II Інтернаціоналу розрив між теорією і практикою, скочуючись у низці найважливіших питань на позиції меньшовикуючого ідеалізму». Звісно, піди розберися на семінарі, про що йдеться, а рекламувати цю баналюку потрібно. 
А от згадка про переверзєвщину («переверзіанство») якраз те, до чого Корнійчук як літератор повинен був мати безпосереднє ставлення i, обурено згадуючи літературознавчу концепцію Валер'яна Федоровича Переверзєва (1882-1968), сконцентровану в його чудовій книзі «Творчість Достоєвського»(1928), сам потерпав акурат від переверзєвщини, на дух її не зносячи.

Не лякайся, читачу, ця модель нескладна.

Зводячи весь літературний процес до двох елементів - стилю й образу, - Переверзєв уважав, що літературний стиль $є$ відтворенням життєвого стилю певної групи, а образи - відтворенням соціального типу певної групи або «соціального характеру».

Він очевидно рухався за думкою Девіда Юма, висловленою 1739 року:

«Шкіра, пори, м'язи і нерви у поденника зовсім інші, ніж у знатної людини; те саме можна сказати про його почуття, вчинки і манери. Різниця в стані впливає на всю організацію [людини], як зовнішню, так і внутрішню; а ця різниця в стані виникає необхідно, оскільки одноманітно, із необхідних і одноманітних принципів людської природи». [37]

Отже, художник створює живі особи, характери, а не систему ідей; аналіз художнього твору повинен бути аналізом живих образів, а не пошуками тих ідей чи поглядів. Людина з усіма ії складнощами, а не ідея 3 усією її величністю, - головне в літературі. Здатність письменника зображувати живі особи і характери Переверзєв дотепно обмежував здатністю зображення лише того страту, до якого належить письменник, дещо механічно зводячи до цього всю проблему «класової детермінованості літературного творчості». Отже, будь-який художній образ містить лише автопортрет певної соціальної групи і будь-яке зображення письменником образів «чужої класової дійсності» 
(наприклад, літератор із селян не може адекватно зобразити поведінку профресора університету: не через те, що не хоче, а через те, що принципово не може - інший життєвий вишкіл) є маскуванням власної класової дійсності. У будь-якому образі, що зображає чужу соціальну групу, такий письменник встановлює лише «переодягненого» представника звичної для письменника соціальної групи.

Такі думки вголос, а тим паче друковано, не можна було виголошувати (правда, книжку про Достоєвського Переверзєв писав ще в царському засланні): більшість радянських письменників тієї доби (та й, природно, надалі) аж ніяк не відносились до інтелігентних верств, і вказувати на їхню обмеженість і «брудні нігті» було в 1920-і образливо і вкрай небезпечно.

Корнійчук та його колеги, звісно, повинні були образитись. Але якщо інші просто надули губки, Євдокимович взяв корисне спостереження Переверзєва до пильної уваги і почав працювати над собою - аби й видно не було, що він із простаків, що може і селянина, і профресора, і шахтаря, і маршала 3 героєм соцпраці адекватно змалювати.

Утім, за Йосифом Бродським, як відомо, головне не результат творчого акту, а велич задуму. Корнійчук дуже старався зробити себе міською людиною, містянином, правильно вимовляти слова і ставити у них наголоси (хоча і вимовляв: Фіндляндія, тубаретка, чеймодан), не переводячи, а силоміць перетягуючи себе зі звичного йому робочого страту в незвичний, але такий привабливий, - інтелігентний. Шкода: не виходило у нього це адекватно, особливо на початку літературної кар'єри.

Але існування пролетписьменників зберігалося й пестувалося, куди ж їм подітися. 
За півстоліття на це зверне увагу Михайло Жванецький, висловившись про радянський кінематографр 1970-х:

«Фрак народ носить разучился. Хамство и грубость в Сибири как раз получается ничего, а образование в Петербурге не идёт пока. Аристократизм в Петербурге пока не идёт. Если герой просто сидит ещё ничего, а как рот откроет - так пока не идёт. Или, там, собственное достоинство, вот эта неприкасаемость личности.... . [38]

«Переверзєвщина», що мала дратувати Корнійчука та його пролетарських колег над усе (якщо вони були здатні розчовпати, про що йдеться), позаяк була спостереженням правдивим і об'єктивно неминучим.

Попри всю завбачливість, Корнійчук не міг знати, що за півроку після публікації його доповіді з'явиться партійна постанова про перебудову літературно-художніх організацій, в якій жодним оспіваним ним РАППам, ВУСППам і «Молоднякам» не буде місця і слід буде швиденько змінювати риторику, а разом з нею спрощувати лексикон. Кому потрібна складність, необхідність вдумуватися в особливості ідейних спрямувань різних творчих течій, в розмаїття думок? Треба робити «простіше і гірше» (Б. В. Орєхов), без надмірної жанрової бароковості висловлювань і тематичної закрученості сюжетів. Корнійчук зорієнтується миттєво: дивіться, як змінилася його риторика.

«Постанова ЦК ВКП(б) від 23 квітня про перебудову мистецьких організацій дала широкі перспективи нашій творчості, звільнила літературу від непотрібної групівщини, засідательства, разом з тим поставила перед кожним письменником надзвичайно відповідальне завдання - дати великі полотна нашої соціалістичної дійсності. Письменник жодної епохи не мав таких багатих, невичерпних можливостей творчості, як радянський письменник» (5 : 122). 
От же ж візантієць, от східний лукавець: «засідательство» - це ж і про свою невлучну тепер доповідь на кінонараді.

Точним нюхом розумної, аналітично витресуваної людини відчув - якщо фрільм трапиться ідеологічно правильним, то добре, його будуть показувати трудящим у кінотеатрах, якщо правильність ідеології зміниться згори, - фрільм заборонять і автору може дістатися на горіхи.

Та й ситуація ставала все більш візантійською. Що це означає?

Спочатку в Константинополі було чотири клуби циркових уболівальників, що різнилися за кольорами одягу візників: ве́нети (сині), пра́сини (зелені), ле́вкії (білі) та ру́сії (червоні)- приблизно як наші літературні угруповання 1920-х (ВУСПП, ВАПЛІТЕ, «Молодняк», «Гарт», «Плуг», «Горно», «Гроно», «Пролітфронт», «Аспис», «Танк», «Жовтень», «Листопад» і «Нова ґенерація»). Поступово візантійська спортивна тетрархія трансформувалась у дуумвірат: сині і зелені, а потім і зовсім вщухла за правління Іраклія або Льва III. У СРСР не стали чекати на імператора Іраклія, оскільки було очевидно, що «змагання за першість, за домінанту, а точніше - чвари і свари, були найпершою відзнакою кожної з цих “панівних" на той час літературних організацій». [39] У серпні 1934-го на Першому з'їзді радянських письменників, скликаному відповідно до постанови 1932 року, створили Союз радянських письменників СРСР (достоту, тавтологічно: «радянських» і «СРСР»; невже передбачалися нерадянські письменники СРСР?), що об'єднав усі напрями [40] й у якому 29-річний Корнійчук одразу зайняв відповідну нішу.

Він розумів: чи варто ризикувати, пишучи веселі (чи які там ще) сценарії? Чи не простіше віддатися театру: п'єса - живий матеріал, можна міняти репліки, «уточнювати ідейну позицію» (як він робив із текстами своїх п'єс аж до 1966 року, до п'ятитомного Зібрання творів), та й старші камрати завжди допоможуть «молодому драматургу». 
Фільм це річ статична: одного разу зняв - і все життя можеш не відмитися.

А театр це життя. Пам'ятаєте: «Oh theatre, — you are the world!»?

«Екран не може дати того, що сцена, - живу людину, її дихання. Кіноактор зіграє раз і назавжди. I перед об'єктивом, а не перед глядачем. Фільм однаковий на будь-якій аудиторії, і його радіолокатор не ловить живої емоції залу.

А в театрі саме це - дихання залу, його вплив, його пульс перетворює талант на геніальність, а середні здібності актора - на талант.

Я завжди втішаю працівників кіно, котрі особливо кохаються на цій проблемі: гарне житиме і у вас, і у нас без виписування безстрокових полемічних паспортів на безсмертя, погане помре. Тому треба менше про те, хто кого, а більше - про якість». [41]

Наприкінці 1932-го Євдокимович відійшов од орг-активних кіносправ.

\section{תimepamypa:}

1. Фрагмент книги «Тривкий тролінґ трикстера: Метадраматургія Олександра Корнійчука», що готується до друку у київському видавництві «Дух і Літера».

2. В. Скуратівський. (2017). 3 кінознавчого записника: Статті в журналі «Кіно-Театр». Київ: Арт-Книга, С. 39-40.

3. С. Тримбач. (2011). Журнал «Кіно» крізь призму часу. «Кіно» (19251933). Сист. покажчик змісту ж-лу, Н. Казакова, Р. Росляк. Київ, Нац. парлам. б-ка України, С. 17.

4. О. Корнійчук. (1930). Темп країни й темп кіна. Кіно. № 2 (74), січ. С. 6.

5. П. Пар. (1932). На підступах до 1933 року. Кіно. № 17/18 [125/126]. С. 6.

6. Іверс. (1932). Перша комсомольська кінокомедія: [перед. слово до сценарію к/ф Одес. кіноф-ки «Приємного апетиту» та про його 
сценаристів О. Корнійчука та Х. Шмаїна]. Кіно. № 17/18 [125/126]. С. 7; О. Корнійчук, Х. Шмаїн. «Приємного апетиту». Уривки зі сценарію. Там само. С. 8-10 (з фотопортретом Ханана Мойсейовича Шмаїна).

7.И. Ильф, Е. Петров. (1975). Золотой телёнок. Москва: Худож. л-ра. С. 267.

8. Іверс. (1933). Позитивний образ в комедійному жанрі (порядком дискусії). Кіно. 1933. № 4 [134]. С. 9-11; Приємного апетиту: [кадри 3 худож. фрільму]. Кіно. 1933. № 3 [133]. С. 5, 10; № 4 [134]. С. 5; С. Войнілович. Глядач хоче сміятися (порядком дискусії). Кіно. 1933. № 4 [134]. C. 5-8.

9. Ю. Кобилецький. (1975). Крила кречета: Крила кречета: Життя і творчість Олександра Корнійчука. Київ, Дніпро, С. 73.

10. По кінофрабриках світу. (1930). Кіно. № 11 (83), трав. С. 14-15.

11. А.Я. Каплер. (1984). Странствия в искусстве. А.Я. Каплер. Избранные произведения: В 2 т. Москва: Искусство, Т. 2. С. 457.

12. Свій хлопець. URL: https://vufku.org/found/svij-khlopets/ 3 невідомих причин автором сценарію «Двох промфінпланів» на цьому сайті вказано письменника і сценариста Вадима Охременка (1900-1940).

13. І. Дузь. (1985). Від задуму до прем'єри: Творча історія п'єс Олександра Корнійчука. Київ, Рад. письменник, С. 25.

14. И. Ильф, Е. Петров. Золотой телёнок. С. 218.

15. І. Дузь. (1978). Золото душі. Пам'ять серця: Спогади про Олександра Корнійчука. Упоряд. Г.П.Донець. Київ, Дніпро, С. 392.

16. Т. Левчук. Велике і щире серце. Пам'ять серця. С. 121.

17. Довженко-центр. URL:

https://www.facebook.com/dovzhenko.centre/posts/1171782709576310/ 18. Т. Пнин. (1995). Зачем Кларе кларнет Карла (в защиту плагиата). Медведь. № 4. С. 126-127. 
19. С. М. Цалик, П. О. Селігей. Олександр Корнійчук (2010). Таємниці червоного Шекспіра. С. М. Цалик, П. О. Селігей. Таємниці письменницьких шухляд: Детективна історія української літератури. Київ, Наш час, С. 116-139.

20. Спроба не лише Гуменної (Д. Гуменна. Дар Евдотеї: Іспит пам'яті: [У 2 кн.]. Балтимор; Торонто: Укр. вид-во «Смолоскип» ім. В. Симоненка, 1990. Кн. 2: Жар і крига. С. 237-238), а й сучасних дослідників зганьбити Корнійчука за допомогою Кордюма наражається ще на такий фракт: дружина Кордюма - Лідія Миколаївна КордюмОстровська (1909-1986) - була ініціатором постановки і режисером документального фрільму «Олександр Корнійчук» до його 65-річчя на студії «Київнаукфрільм» (1970). Навіщо б їй знімати фрільм про плагіатора «зі стажем» твору свого померлого чоловіка?

21. В. Кукель. (1923). Правда о гибели Черноморского фрлота в 1918 году. Петроград: Тип. Морского ведомства в Главном Адмиралтействе, $120 \mathrm{c}$.

22. І. Дузь. Від задуму до прем'єри... С. 26.

23. І. Ле. В ті далекі роки... Пам'ять серця. С. 63.

24. С. М. Цалик, П. О. Селігей. Олександр Корнійчук: Таємниці червоного Шекспіра... С. 128.

25. К. Рудик. Свій до свого по чуже: кінокрадство по-радянськи. ЛітАкцент. 2019. 28 січня. URL: http://litakcent.com/2019/01/28/sviy-dosvogo-po-chuzhe-kinokradstvo-po-radyanski/

26. Н. Ужвій. Співець життя народного. Пам'ять серця. С. 42.

27. Й. Гірняк. (1974). До недобитків «Березоля»: Відкритий лист 3 приводу хрипливих франфар позолоченого ювілею. Сучасність. Мюнхен, 1974. Лютий. Ч. 2 (158). С. 15-16.

28. Н. Кузякіна.: [В 2 ч.] Київ, Рад. письменник, 1958. Ч. 1, 1917-1934. С. 182. 
29. О. Корнійчук. (1931). Творча метода української радянської кінематографії: Скорочена стенограма доповіді на І кінонараді при ЦК ЛкСМУ. Молодняк. Харків, № 9. С. 57.

30. Там само. С. 61.

31. Там само. С. 66.

32. Там само. С. 61.

33. Там само. С. 67.

34. Там само. С. 65.

35. Там само. С. 68-69.

36. Там само. С. 57.

37. Д. Юм. (1996). Трактат о человеческой природе. Д. Юм. Сочинения:

В 2 т. Москва, Мысль, Т. 1. С. 445-446.

38. М. Жванецкий. (2004). Собрание произведений: [В 5 т.] Москва, Время, Т. 3. С. 13-14.

39. Ю. Смолич. (1986). Йогансен. Ю. Смолич. Твори: У 8 т. Київ, Дніпро, Т. 7: Розповіді про неспокій. С. 138.

40. Вадим Перельмутер потім скаже: боротьба офріційної радянської літератури за право писати погано успішно завершилася перемогою над формалізмом.

41. О. Корнійчук. (1968). Роздуми, спогади, діалоги (1965). О. Корнійчук. Твори: В 5 т. Київ, Дніпро, Т. 5. С. 254.

\section{References:}

1. Frahment knyhy «Tryvkyi troling trykstera: Metadramaturhiia Oleksandra Korniichuka», shcho hotuietsia do druku u kyivskomu vydavnytstvi «Dukh i Litera».

2. V. Skurativskyi. (2017). Z kinoznavchoho zapysnyka: Statti v zhurnali «Kino-Teatr». Kyiv: Art-Knyha, S. 39-40. 
3. S. Trymbach. (2011). Zhurnal «Kino» kriz pryzmu chasu. «Kino» (19251933). Syst. pokazhchyk zmistu zh-lu, N. Kazakova, R. Rosliak. Kyiv, Nats. parlam. b-ka Ukrainy, S. 17.

4. O. Korniichuk. (1930). Temp krainy y temp kina. Kino. № 2 (74), sich. S. 6.

5. P. Par. (1932). Na pidstupakh do 1933 roku. Kino. № 17/18 [125/126]. S. 6.

6. Ivers. (1932). Persha komsomolska kinokomediia: [pered. slovo do stsenariiu k/f Odes. kinof-ky «Pryiemnoho apetytu» ta pro yoho stsenarystiv O. Korniichuka ta Kh. Shmaina]. Kino. № 17/18 [125/126]. S. 7; O. Korniichuk, Kh. Shmain. «Pryiemnoho apetytu». Uryvky zi stsenariiu. Tam samo. S. 8-10 (z fotoportretom Khanana Moiseiovycha Shmaina). 7.Y. Ylf, E. Petrov. (1975). Zolotoi telënok. Moskva: Khudozh. I-ra. S. 267.

8. Ivers. (1933). Pozytyvnyi obraz $v$ komediinomu zhanri (poriadkom dyskusii). Kino. 1933. № 4 [134]. S. 9-11; Pryiemnoho apetytu: [kadry z khudozh. filmu]. Kino. 1933. № 3 [133]. S. 5, 10; № 4 [134]. S. 5; S. Voinilovych. Hliadach khoche smiiatysia (poriadkom dyskusii). Kino. 1933. № 4 [134]. S. 5-8.

9. Yu. Kobyletskyi. (1975). Kryla krecheta: Kryla krecheta: Zhyttia i tvorchist Oleksandra Korniichuka. Kyiv: Dnipro, S. 73.

10. Po kinofabrykakh svitu. (1930). Kino. № 11 (83), trav. S. 14-15.

11. A. Ya. Kapler. (1984). Stranstvyia v yskusstve. A. Ya. Kapler. Yzbrannыe proyzvedenyia: V 2 t. Moskva: Yskusstvo, T. 2. S. 457.

12. Svii khlopets. URL: https://vufku.org/found/svij-khlopets/ Z nevidomykh prychyn avtorom stsenariiu «Dvokh promfinplaniv» na tsomu saiti vkazano pysmennyka i stsenarysta Vadyma Okhremenka (1900-1940).

13. I. Duz. (1985). Vid zadumu do premiery: Tvorcha istoriia pies Oleksandra Korniichuka. Kyiv, Rad. pysmennyk, S. 25.

14. Y. YIf, E. Petrov. Zolotoi telënok. S. 218. 
15. I. Duz. (1978). Zoloto dushi. Pamiat sertsia: Spohady pro Oleksandra Korniichuka. Uporiad. H. P. Donets. Kyiv, Dnipro, S. 392.

16. T. Levchuk. Velyke i shchyre sertse. Pamiat sertsia. S. 121.

17. Dovzhenko-tsentr. URL:

https://www.facebook.com/dovzhenko.centre/posts/1171782709576310/

18. T. Pnyn. (1995). Zachem Klare klarnet Karla ( $v$ zashchytu plahyata). Medved. № 4. S. 126-127.

19. S. M. Tsalyk, P. O. Selihei. Oleksandr Korniichuk (2010). Taiemnytsi chervonoho Shekspira. S. M. Tsalyk, P. O. Selihei. Taiemnytsi pysmennytskykh shukhliad: Detektyvna istoriia ukrainskoi literatury. Kyiv, Nash chas, S. 116-139.

20. Sproba ne lyshe Humennoi (D. Humenna. Dar Evdotei: Ispyt pamiati: [U 2 kn.]. Baltymor; Toronto: Ukr. vyd-vo «Smoloskyp» im. V. Symonenka, 1990. Kn. 2: Zhar i kryha. S. 237-238), a y suchasnykh doslidnykiv zghanbyty Korniichuka za dopomohoiu Kordiuma narazhaietsia shche na takyi fakt: druzhyna Kordiuma - Lidiia Mykolaivna Kordium-Ostrovska (1909-1986) - bula initsiatorom postanovky i rezhyserom dokumentalnoho filmu «Oleksandr Korniichuk» do yoho 65-richchia na studii «Kyivnaukfilm» (1970). Navishcho b yii znimaty film pro plahiatora «zi stazhem» tvoru svoho pomerloho cholovika?

21. V. Kukel. (1923). Pravda o hybely Chernomorskoho flota $v 1918$ hodu. Petrohrad: Typ. Morskoho vedomstva v Hlavnom Admyralteistve, $120 \mathrm{~s}$.

22. I. Duz. Vid zadumu do premiery... S. 26.

23. I. Le. V ti daleki roky... Pamiat sertsia. S. 63.

24. S. M. Tsalyk, P. O. Selihei. Oleksandr Korniichuk: Taiemnytsi chervonoho Shekspira... S. 128.

25. K. Rudyk. Svii do svoho po chuzhe: kinokradstvo po-radiansky. LitAktsent. 2019. 28 sichnia. URL: http://litakcent.com/2019/01/28/sviy-dosvogo-po-chuzhe-kinokradstvo-po-radyanski/ 
26. N. Uzhvii. Spivets zhyttia narodnoho. Pamiat sertsia. S. 42.

27. Y. Hirniak. (1974). Do nedobytkiv «Berezolia»: Vidkrytyi lyst z pryvodu khryplyvykh fanfar pozolochenoho yuvileiu. Suchasnist. Miunkhen, 1974. Liutyi. Ch. 2 (158). S. 15-16.

28. N. Kuziakina.: [V 2 ch.] Kyiv, Rad. pysmennyk, 1958. Ch. 1, 1917-1934. S. 182.

29. O. Korniichuk. (1931). Tvorcha metoda ukrainskoi radianskoi kinematohrafii: Skorochena stenohrama dopovidi na I kinonaradi pry TsK LKSMU. Molodniak. Kharkiv, № 9. S. 57.

30. Same. S. 61.

31. Same. S. 66.

32. Same. S. 61.

33. Same. S. 67.

34. Same. S. 65.

35. Same. S. 68-69.

36. Same. S. 57.

37. D. Yum. (1996). Traktat o chelovecheskoi pryrode. D. Yum. Sochynenyia: V 2 t. Moskva, Mysl, T. 1. S. 445-446.

38. M. Zhvanetskyi. (2004). Sobranye proyzvedenyi: [V 5 t.] Moskva, Vremia, T. 3. S. 13-14.

39. Yu. Smolych. (1986). Yohansen. Yu. Smolych. Tvory: U 8 t. Kyiv, Dnipro, T. 7: Rozpovidi pro nespokii. S. 138.

40. Vadym Perelmuter potim skazhe: borotba ofitsiinoi radianskoi literatury za pravo pysaty pohano uspishno zavershylasia peremohoiu nad formalizmom.

41. O. Korniichuk. (1968). Rozdumy, spohady, dialohy (1965). O. Korniichuk. Tvory: V 5 t. Kyiv, Dnipro, T. 5. S. 254. 
Copyright: Andrii Puchkov (C. 2020. This is an openaccess article distributed under the terms of the Creative Commons Attribution License (CC BY). The use, distribution or reproduction in other forums is permitted, provided the original author(s) or licensor are credited and that the original publication in this journal is cited, in accordance with accepted academic practice. No use, distribution or reproduction is permitted which does not comply with these terms. 